\title{
Analysis of The Actuating of The Rehabilitation Program House is not Unitable in Palembang City
}

\author{
M. Febrianza ${ }^{\mathrm{a}}$, Sutinah $^{\mathrm{b}} *$ \\ ${ }^{\mathrm{a}, \mathrm{b}}$ Department of Public Administration STISIPOL Candradimuka, Palembang, South Sumatera, Indonesia
}

\section{ARTICLE INFORMATION ABSTRACT}

\section{Article history:}

Data submission : 12 May 2020

$1^{\text {st }}$ revision: 22 June 2020

Accepted: 12 August 2020

Available online: 25 November 2020

Keywords: Actuating, Implementing, the Rehabilitation of Unfit for Living (RTLH) Program

\begin{abstract}
This study examines the dimension of drivers in the implementation of the unworthy housing program in Palembang City. Data were analysed using an interactive model which includes three components of the analysis, namely reduction, data presentation, and conclusion drawing. The results showed that based on the planning dimension, the limited amount of budget owned by the government when compared to Mobilization, the socialization carried out was not optimal, the community was quite enthusiastic about participating in the unfit home rehabilitation program in Palembang City by building their own houses. However, development is being carried out quite slowly due to a lack of expertise and due to the busyness of the community making a living. To overcome this, it is necessary to motivate the community to carry out the construction of their houses, including giving wages.
\end{abstract}

2020FIA UB. All rights reserved.

\section{Introduction}

Law No. 1 of 2011 concerning Housing and Settlement Areas, defines Housing and Settlement areas as a unitary system consisting of development, housing management, settlement area management, maintenance and repair, prevention and quality improvement of slum housing and slum settlements, land provision, funding and financing system, as well as the role of the community. There are 59 sub-districts from 12 subdistricts in Palembang City that have been designated as slum settlement locations. Of the 59 Kelurahan, the slum settlement locations consist of three categories, namely light slum, moderate slum and heavy slum. Of the 12 sub-districts that are locations for slum settlements in Palembang City, there are two subdistricts that are categorized as heavy slums, namely Kertapati District and Sebelang Ulu I District.

The number of target communities receiving assistance in 2016 was 391 heads of households (KK) and then increased in 2017 to 554 households. Apart from the limited amount of the budget, the lack of the number of human resources (staff) means that field supervision cannot be carried out optimally, this is because the number of personnel is not proportional to the area that must be handled. Therefore, through the delegation of authority to sub-districts and sub-districts it is hoped that the supervisory function will run better, because supervision in policy implementation is a very crucial factor. As stated by Purwanto (2012), many failures in implementing a policy are partly due to weak oversight mechanisms. (Source: Department of Public Housing and Settlement Areas of Palembang City in 2019).

Based on the identification of these problems, the formulation of the problem in this study is: "How to Activate the Rehabilitation Program for Unworthy Houses in Palembang City?"

\section{Theory}

G.R Terry management is: "Management is a distinc process consisting of planning, organizing, actuating and controlling performed to determine and accomplish 
stated objectives by the use of human being and other resources. (Management is a typical process consisting of planning, organizing, directing and controlling actions that are carried out to determine and achieve predetermined goals through the use of human resources and other resources (Terry in Hasibuan, 1996: 2). Implementation according to Terry (in Manullang, 2005: 3 ) consists of 4 dimensions, namely planning, organizing, mobilizing and controlling, in this study focused on the dimension of movement

According to Law No. 1 of 2011 concerning Housing and Settlement Areas in article 1 of the definition of housing and residential areas is an integrated system consisting of development, management of housing, management of residential areas, maintenance and repair, prevention and quality improvement of slum housing and slum settlements, provision of land, funding and financing system, as well as the role of the community. Based on Article 2 of Law No. 1 of 2011 concerning Housing and Settlement Areas, housing and residential areas is organized on the basis of:
a. Well-being
b. Justice and equity
c. Nationalism
d. Efficiency and expediency
e. Affordability and convenience
f. Independence and togetherness
g. Partnership
h. Harmony and balance
i. Cohesiveness
j. Health
k. Sustainability and sustainability, and
1. Safety, security, order and order

Article 4 of Law No. 1 of 2011 concerning Housing and Settlement Areas states that the arrangement of housing and settlements aims to:

a. Fulfilling the needs of a house as one of the basic human needs in order to increase and distribute people's welfare.

b. Creating adequate housing and settlements in a healthy, safe, harmonious and orderly environment.

c. Provide direction for regional growth and rational population distribution.

d. Supporting development in the economic, social, cultural and other fields.

According to the Regulation of the Minister of Social Affairs of the Republic of Indonesia No. 20 of 2017 concerning Social Rehabilitation of Uninhabitable Houses and Environmental Infrastructure, Unfit for Living Houses is a place to live that does not meet health, security, and social requirements. Unfit for habitation is a dwelling or place to live that is not suitable for habitation because it does not meet the requirements for housing both technically and nontechnically. In general, houses that are not suitable for habitation are closely related to slum settlement because basically in the slum areas there is a picture of community poverty.

a) Indicators of the Program for Unfit for Living in Palembang City

This study looked at the policy from the implementation aspect, namely the implementation of the Rehabilitation Program for Unfit for Living Houses in Palembang City. Furthermore, the process of implementing activities that takes place, even though what is seen is the process. Following are indicators of the implementation of the Unworthy Housing Rehabilitation Program in Palembang City which is based on the Theory of Implementation Management Principles, from Terry (in Manullang, 2005: 3), the Mobilization dimension consists of the indicator
a. Socialization
b. Proposing a request for assistance
c. Disbursement of assistance
d. Implementation of development
e. Society participation

\section{Research Method}

This study uses a qualitative approach with the consideration that in this study the researcher intends to gain a deep understanding of the Mobilization of the Unworthy Housing Program in Palembang City. The method or approach used is a qualitative method.

The variable in this study is an independent variable, namely "Implementation of the Rehabilitation Program for Unfit for Living in Palembang City". This variable is independent because it is not associated with other variables. In line with this, the focus of this research is the Mobilization of the Unworthy Housing Program in Palembang City which is analyzed through planning, organizing, mobilizing and monitoring. The operational definition is used to see the Movement of the Unfit for Living Home Program in Palembang City by using Terry's theory of implementation management principles (in Manullang, 2005: 3), especially the dimensions of Mobilization as follows:
a. Socialization
b. Proposing a request for assistance
c. Disbursement of assistance
d. Implementation of development
e. Society participation

The unit of analysis is the unit to be researched or analyzed (Singarimbun and Efendi, 1995: 155). The units of analysis in this study are:

a. Organization, namely the Department of Public Housing and Settlement Areas of Palembang City.

b. Individuals, namely the Head of the Formal Housing Section of the Public Housing and Settlement Areas of Palembang City, Employees of the Palembang City Public Housing and Settlement Service, the Head of 
RT 16 Ogan Baru Village as Informants, Field Facilitators (TFL) and the target community for the Rehabilitation Program Unfit for Living in Palembang City

The data used in this study comes from primary data, namely data from interviews and secondary data from documents and reports. The data collection technique used in this study is to use the method of interviewing, observation and literature study. Data analysis in this study will use an interactive model from Miles, Huberman, Saldana (2014: 20) which includes four components of analysis, namely data collection, data condensation, data display and a conclusion.

\section{Results}

This research with the title Effectiveness of the Implementation of the Uninhabitable House Program in Palembang City takes the focus of research which is located on the Effectiveness of the Implementation of the Unfit for Living in Palembang City Program which includes planning, organizing, mobilizing and monitoring. Data regarding the Implementation of the Rehabilitation Program for Unfit for Living in Palembang City was collected by field researchers using interview techniques. Interview activities were carried out from September 1 to September 102020 with a predetermined key informant.

As for those who became informants in this study, namely:

1) Head of the Formal Housing Section of the Public Housing and Settlement Areas of Palembang City, as Informant 1

2) Employees of the Public Housing and Settlement Areas of Palembang City, as Informants 2

3) Employees of the Public Housing and Settlement Areas of Palembang City, as Informants 3

4) Head of RT 16 Kelurahan Ogan Baru as Informant 4

5) Field Facilitators (TFL) as Informants 5

6) Field Facilitators (TFL) as Informants 6

7) The target community for the Rehabilitation of Unworthy Houses in Palembang City as Informants 7

8) The target community for the Rehabilitation of Unfit for Living in Palembang City as Informants 8

9) The target community for the Rehabilitation of Unworthy Houses in Palembang City as Informants 9

The results of the analysis of each of these subvariables can be seen as follows:

\subsection{Socialization}

The socialization of the Rehabilitation Program for Unfit for Living in Palembang City was carried out, one of which was by holding a meeting between the Palembang City Government, in this case the Public Housing and Settlement Areas of Palembang City, with aid recipients and related parties. However, the socialization was not optimal. Even with the recipients of assistance, the socialization provided is not optimal, especially if we compare it to people who do not receive assistance, even though community involvement in the success of the policy can affect the success of achieving policy objectives.

\subsection{Proposing a request for assistance}

Submission of requests for assistance from the Unworthy Housing Program (RTLH) in Palembang City is carried out by the community-to-community organizations, in this case the Community Self-Reliance Institution (LKM), which is then verified by the village head to be addressed to the Mayor of Palembang.
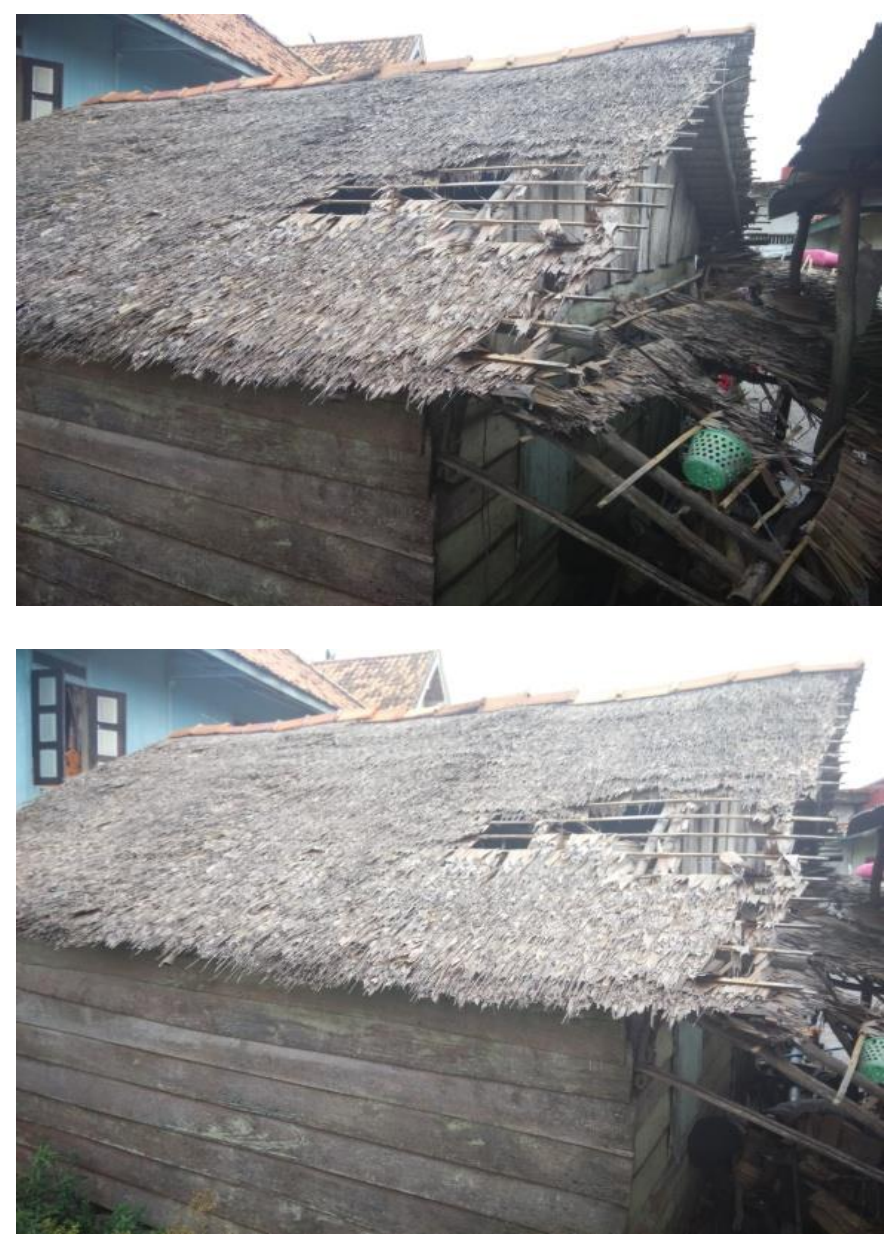

Figure 1: Example of Proposing a Request for Assistance for the Unfit for Living (RTLH) Program in Palembang City (assisted by the Roof)

Source: Department of Public Housing and Settlement Areas of Palembang City

\subsection{Disbursement of assistance}

The disbursement of assistance from the Unfit for Living (RTLH) Program has been implemented by the City Government of Palembang, in this case the Public Housing and Settlement Areas of Palembang City based 
on the work weight of the proposal that has been verified by related parties.

\subsection{Implementation of development}

The implementation of the Construction of Unfit for Living (RTLH) Program in Palembang City is carried out by the community itself in mutual cooperation. Here are some pictures of house conditions that are still under construction

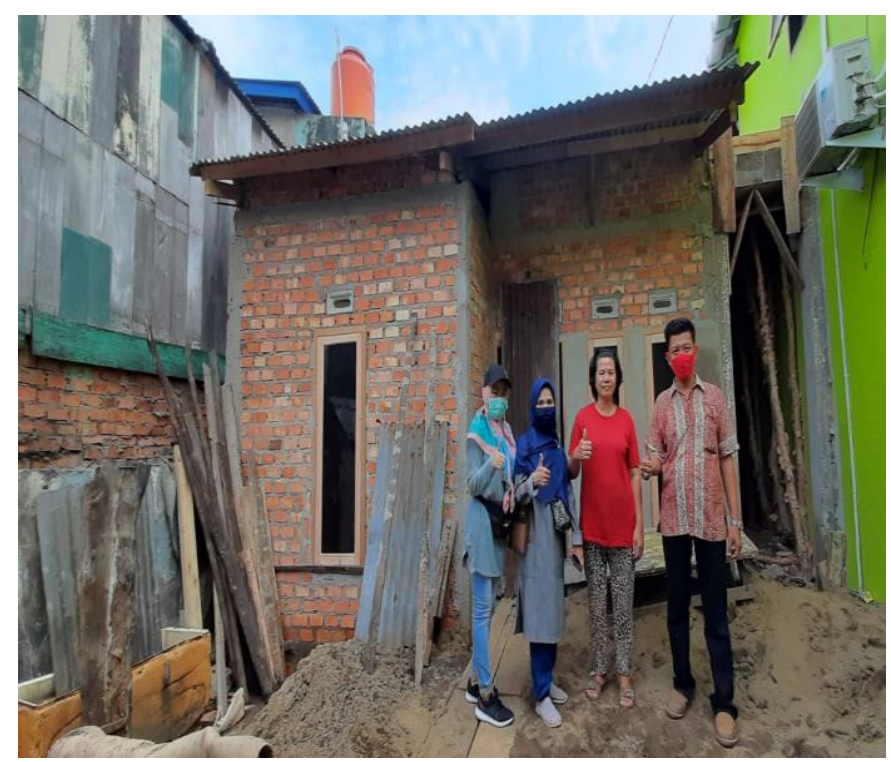

Figure 2: Informant's House Construction Process 7, which was originally only a tarp house

Source: Researcher's Documentation

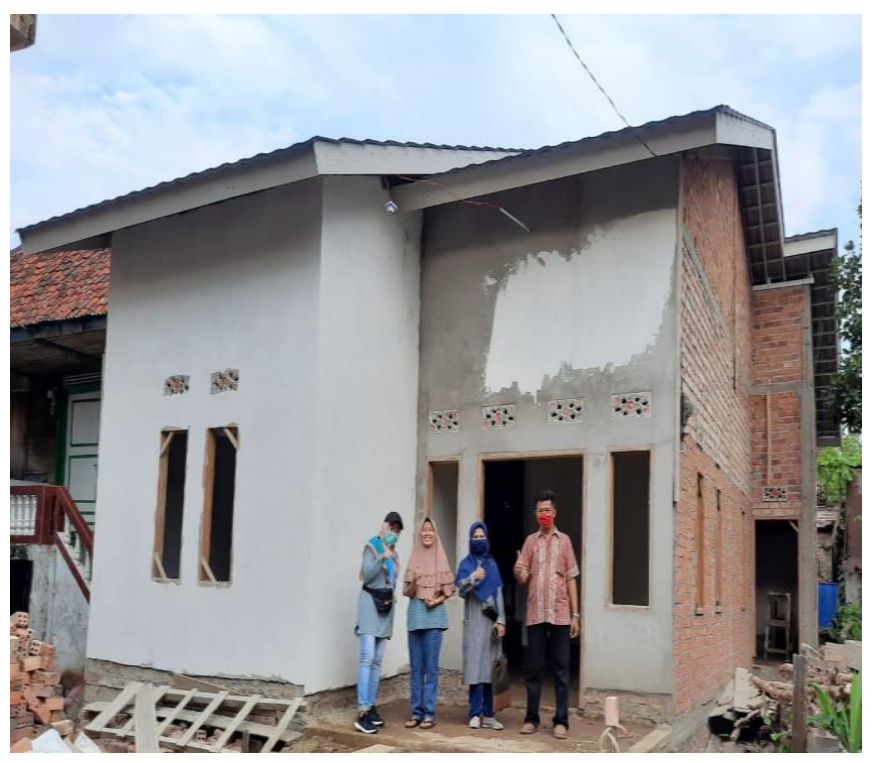

Figure 3: The Process of Building Informants' Houses 8, which the family also supports

Source: Researcher's Documentation
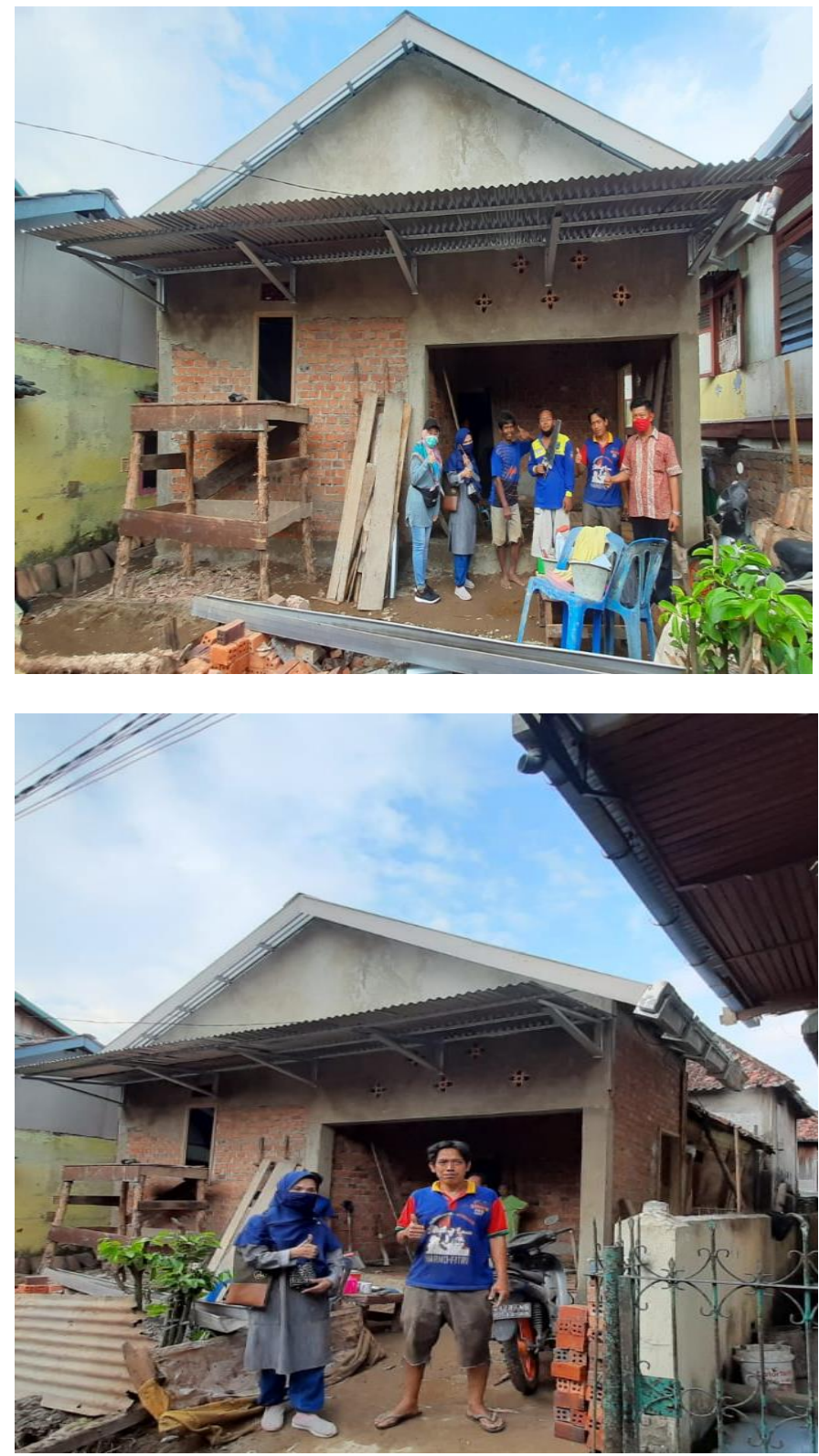

Figure 4: Informant House Construction Process 9, which left the old (wooden) building behind because it was still short of funds Source: Researcher's Documentation

\subsection{Society participation}

The community is quite enthusiastic about participating in the Rehabilitation Program for Unworthy Houses in Palembang City by building their own houses. However, development is being carried out quite slowly due to a lack of expertise and due to the busyness of the community making a living. To overcome this, it is necessary to motivate the community to carry out the construction of their houses, including giving wages. 

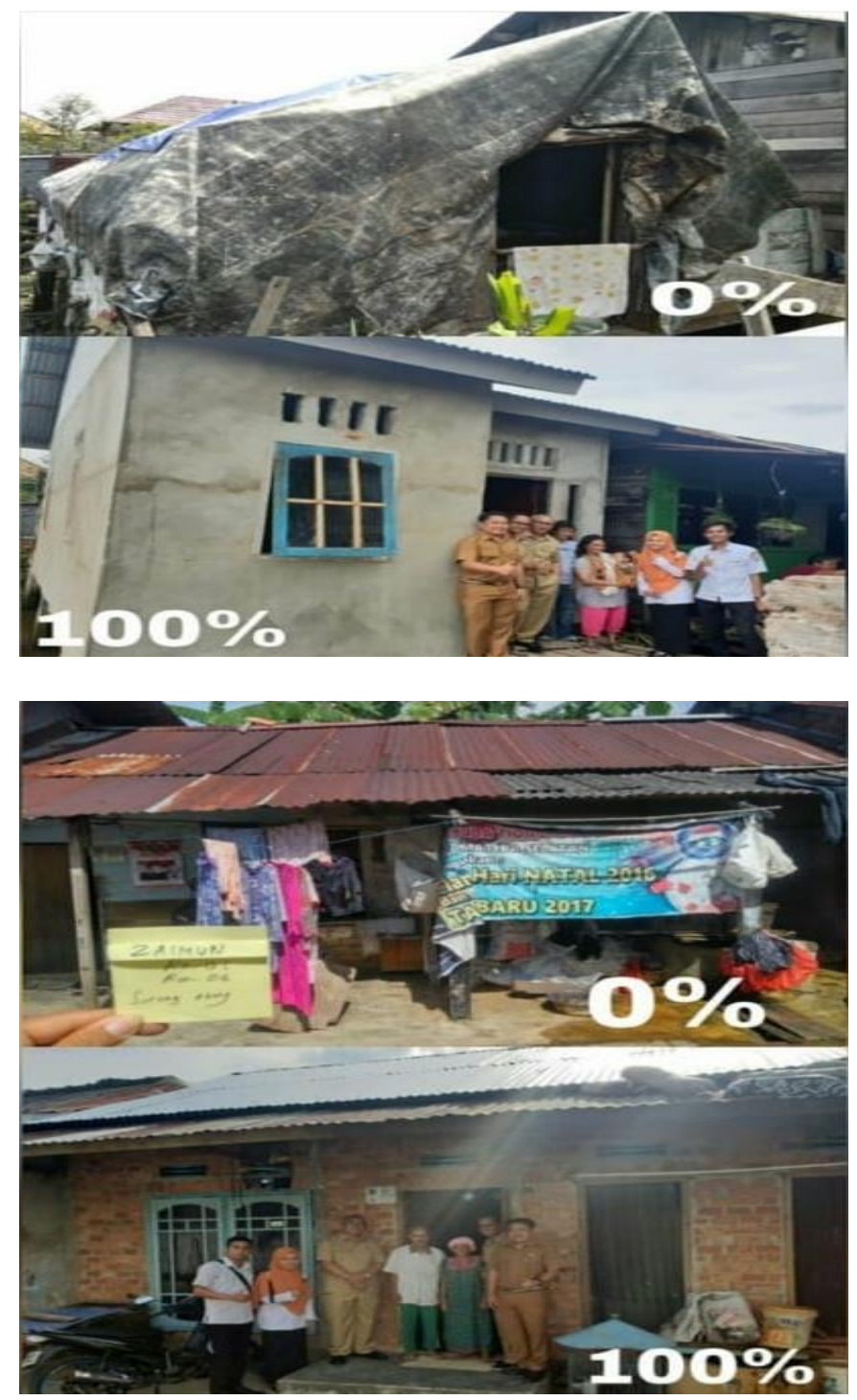

Figure 5: Pictures of housing conditions before and after the Rehabilitation Program for Unfit for Living Houses in Palembang City

Source: Department of Public Housing and Settlement Areas of Palembang City

\section{Discussion and conclusion}

This study concludes that the Implementation of the Rehabilitation Program for Unfit for Living Houses in the City of Palembang is running quite effectively, but still experiencing several obstacles which are described in each of the research dimensions as follows.

First, based on the planning dimension, the limited amount of budget owned by the government when compared with the number of people proposed as beneficiaries of assistance, is not proportional to the number of existing target communities, resulting in bias in proposing and verification. Lack of human resources in helping the process of running this government program in realizing activities to meet the needs of livable houses in Palembang City

Second, based on the Organizing dimension, the implementation of the Unworthy Housing Program
(RTLH) is carried out by the City Government of Palembang, in this case the Public Housing and Settlement Areas of Palembang City with the local village head and community organizations in this case the Community Self-Reliance Institution (LKM). However, coordination is still constrained by time, so persuasive efforts are made both during and outside of work hours

Third, based on the Actuating dimension, the socialization carried out was not optimal, the community was quite enthusiastic about participating in the Rehabilitation Program for Unworthy Houses in Palembang City by building their own houses. However, development is being carried out quite slowly due to a lack of expertise and due to the busyness of the community making a living. To overcome this, it is necessary to motivate the community to carry out the construction of their houses, including giving wages

Fourth, based on the dimension of Control (Controlling), internal supervision is carried out through the formation of an internal supervisory team by the Palembang City Public Housing and Housing Agency which is tasked with supervising and inspecting the work carried out by; provide facilities in the form of facilities and infrastructure (material) required for the smooth execution of work in accordance with the provisions. External supervision was carried out by the Palembang City Public Housing and Settlement Service by involving related parties in the form of the Head of Sub-District, Head of Village and Community SelfReliance Institutions (LKM). However, external supervision in the Implementation of the Rehabilitation Program for Unfit for Living Houses in Palembang City, is still difficult to do considering the vast area of supervision / the large number of people receiving assistance from the Unfit for Living Home Rehabilitation Program in Palembang City. So that often the recipients of house rehabilitation assistance are not suitable for habitation.

\section{References}

Arikunto, Suharsimi. 2010. Prosedur Penelitian Suatu Pendekatan Praktek. Jakarta: Rineka Cipta.

Budiharjo, Eko. 1998. Percikan Masalah Arsitektur, Perumahan, Perkotaan. Yogyakarta: Gadjah Mada University Press.

Dunn, William. N. 2001. Analisis Kebijakan Publik. Yogyakarta: Gajah Mada Univ. Press.

Effendy, Khasan. 2010. Memadukan Metode Kuantitatif Kualitatif. Bandung: CV. Indra Prahasta.

Hasibuan, Malayu S.P. 1996. Manajemen Dasar, Pengertian dan Masalah. Edisi Kedua. Jakarta: PT Toko Gunung Agung.

Hendriwan. 2003. Penanggulangan Kemiskinan Dalam Kerangka Kebijakan Desentralisasi. Yogyakarta: PT. Tiara Wacana. 
Keputusan Walikota Palembang No. 488 Tahun 2016 Tentang Penetapan Lokasi Kawasan Permukiman Kumuh.

Keputusan Walikota Palembang No. 230a Tahun 2014 tentang Penetapan Daftar Penerima dan besaran Bantuan Sosial Untuk Perbaikan Rumah Tidak Layak Huni.

Kuswartojo, Tjuk dan Suparti A. Salim. 1997. Perumahan dan Pemukiman yang Berwawasan Lingkungan. Jakarta: Direktoral Jenderal Pendidikan Tinggi Departemen dan Kebudayaan.

Mangkusoebroto, Guritno. 1993. Ekonomi Publik. Yogyakarta: BPFE.

Manullang. 2005. Manajemen Sumber Daya. Manusia. Alih Bahasa Yogyakarta: Andi Offset

Miles, M. B., Huberman, A. M. and Saldana, J. 2014. Qualitative Data Analysis, A Methods Sourcebook, Edition 3. USA: Sage Publications.

Moeleong, Lexy J. 2011. Metodologi Pendekatan Kualitatif, Edisi Revisi, Bandung: Remaja Rosida Karya.

Peraturan Menteri Sosial Republik Indonesia No. 20 Tahun 2017 tentang Rehabilitasi Sosial Rumah Tidak Layak Huni dan Sarana Prasarana Lingkungan.

Peraturan Menteri Negara Perumahan Rakyat Republik Indonesia Nomor: 22/Permen/M/2008 tentang Standar Pelayanan Minimal Bidang Perumahan Rakyat Daerah Provinsi dan Daerah Kabupaten/Kota.

Purwanto. 2012. Metodologi Penelitian Kuantitatif untuk Psikologi dan Pendidikan. Yogyakarta: Pustaka Pelajar Offset.

Riyadi dan Deddy Supriyadi Bratakusumah. 2005. Perencanaan Pembangunan Daerah. Jakarta: PT Gramedia Pustaka Utama.

Singarimbun, Masri dan Sofian Effendi. 1995. Metode Penelitian Survai. Jakarta: LP3ES.

Soetandoyo, WS. 1996. Metode Kualitatif Vs Metode Kuantitatif. Surabaya: FISIP UNAIR.

Strauss, Anselm, dan Corbin Juliet. 2003. Dasar-Dasar Penelitian Kualitatif. Yogyakarta: Pustaka Pelajar

Sugiyono. 2012. Metode Penelitian Administrasi. Bandung: Alfabeta.

Suryahadi, Asep dan Sumarto. 2001. Memahami Kemiskinan Kronis dan Kemiskinan Sementara di Indonesia. Jakarta: Smeru Newsletter.

Swastha, Basu dan Irawan. 1999. Manajemen Pemasaran Modern. Edisi 2. Yogyakarta: Liberty

Syarief, Zulfie. 2000. Kebijakan Pemerintah di Bidang Perumahan dan Permukiman bagi Masyarakat Berpendapatan Rendah. Medan: USU Press.

Terry, George R. 2005. Office Management and Control, Fourth Edition: terjemahan. Homewood, Ilinois: Richard D. Irwin Inc.

Undang-Undang Dasar (UUD) Tahun 1945.

Undang-Undang No. 1 Tahun 2011 tentang Perumahan dan Kawasan Permukiman.
Wahab, Abdul. 2002. Analisis Kebijakan (Dari Formulasi Ke Implementasi) Kebijakan Negara. Jakarta: Bumi Aksara.

Westra, Pariata dkk. 2001. Ensiklopedia Administrasi. Jakarta: Gunung Agung.

Wibawa, Samudra. 2004. Kebijakan Publik Proses dan Analisis. Jakarta

Yudohusodo, Siswono dkk. 1991. Rumah Untuk Seluruh Rakyat. Jakarta: INKOPPOL. 